\title{
EquiLIBRIUM
}

Quarterly Journal of Economics and Economic Policy

2016 VOLUME 11 ISSUE 2, June

p-ISSN 1689-765X, e-ISSN 2353-3293

www.economic-policy.pl

Cieślik, A. (2016). Exports Versus FDI in Smith-Motta Framework. Equilibrium. Quarterly Journal of Economics and Economic Policy, 11(2), 189-218. DOI: http://dx.doi.org/10.12775/ EQUIL.2016.009

Andrzej Cieślik*

University of Warsaw, Poland

\section{Exports Versus FDI in Smith-Motta Framework ${ }^{* *}$}

\section{JEL Classification: $F 23$}

Keywords: exporting; foreign direct investment; proximity-concentration tradeoff

\begin{abstract}
In this paper we study the choice between exporting and foreign direct investment (FDI) in the Smith-Motta duopoly framework. First, we identify the conditions necessary for exporting and FDI, depending on the costs of exporting and the cost of foreign investment. Then, we discuss various proximityconcentration tradeoffs. Finally, we demonstrate that six possible types of equilibriums may emerge depending on various combinations of the key parameters of the model. These equilibriums include: a monopoly FDI equilibrium, a monopoly exporting equilibrium, a domestic monopoly equilibrium, a duopoly FDI equilibrium, a duopoly exporting equilibrium, and no entry equilibrium.
\end{abstract}

\section{Introduction}

There is extensive literature on the relationship between exporting and FDI. In this literature, several strands can be distinguished. According to the earliest strand, based on the neoclassical theory of international capital movements, FDI and trade were seen as substitutes (Mundell, 1957). This approach was, however, criticized because of relying on the set of unrealis-

(C) Copyright Institute of Economic Research

Date of submission: April 18, 2015; date of acceptance: January 24, 2016

*Contact: cieslik@wne.uw.edu.pl, FES, University of Warsaw, Długa 44/50, 00-241 Warsaw, Poland

** The Author would like to thank two anonymous referees for their helpful comments and suggestions on the previous version of this paper. 
tic assumptions, such as constant returns to scale (CRS) and perfect competition, which were not in line with the key stylized facts on FDI. ${ }^{1}$ Another problem was that in the neoclassical approach firms were infinitely small, and it was not possible to study directly the foreign direct investment decisions that took place within the firm.

Therefore, in the 1970s a new strand in the FDI literature that attempted to model the firm decision to produce abroad under increasing returns and imperfect competition was initiated. In particular, Copithorne (1971), Horst (1971), and Hirsch (1976) attempted to model an exporting versus FDI decision of a monopolist using a simple partial equilibrium framework. ${ }^{2}$ In this framework the firm faced a trade-off between proximity to the foreign market obtained by setting up production plants abroad, which allowed to economize on transportation and tariff costs, and concentration of production in the home country and serving foreign markets by exporting, which allowed to economize on fixed costs of duplicating production capacity abroad. According to this framework, the firm would invest abroad in those industries in which the gains from avoiding trade costs outweighed the costs of setting up production plants abroad.

In the 1980s the New Theory of Multinational Enterprise (NTME) has emerged. The development of the NTME has been the consequence of the emergence of the New Trade Theory (NTT) in the late 1970s and early 1980 s, which was based on the tools borrowed from the industrial organization (IO) literature and allowed for modeling imperfectly competitive market structures other than simple monopoly. In particular, the NTT models embedded increasing returns to scale and imperfectly competitive market structures such as perfect monopolistic competition or various forms of oligopoly. Although particular models differed with respect to assumptions concerning the market structure, their main prediction was very similar: firms were more likely to enter the foreign market via FDI rather than via exporting the higher were the trade costs and the lower fixed costs of entry and the size of economies of scale at the plant level compared to the firm level.

${ }^{1}$ See, for example, Markusen (2002), Barba Navaretti and Venables (2004) and Caves (2007). In particular, Markusen (2002, p. 6) noted that: i) "large differences exist across industries in the degree to which production and sales are accounted for by multinational firms", ii) "multinationals tend to be important in industries that a) have high levels of R\&D relative to sales, b) employ large number of professional and technical workers as a percentage of their total workforces, c) produce new and/or technologically complex products".

${ }^{2}$ See chapter 2 in Caves (2007) for a survey of the early literature on the choice between exporting and FDI. 
Krugman (1983) made one of the earliest attempts to integrate formally multinational enterprises (MNEs) into the NTT. He extended his earlier general equilibrium model of international trade under monopolistic competition (Krugman, 1979, 1980) to introduce the possibility of multinational production. He considered a simple two country framework with labor as the sole factor of production. In addition, he assumed that countries were exactly the same in terms of their labor endowments. The symmetry of the model setup implied wage equalization across countries, which greatly simplified the analysis. More complex, two factor models based on monopolistic competition were proposed by Markusen and Venables (1998) and Markusen (2002, ch. 8). However, their models could not be solved analytically and the authors had to rely on numerical methods to study the properties of the equilibrium solutions.

An alternative early approach based on the model of oligopolistic competition was developed by Markusen (1984). His model assumed the existence of firm-level scale economies as the driving force for FDI. The MNE's headquarter produced a service of a firm-specific asset that could be simultaneously used in multiple plants in a non-rival manner. As a result, two-plant firms had lower fixed costs than those of two single plants and this motivated multinational production. The approach proposed by Markusen (1984) was later extended in the number of follow-up studies, including, inter alia, Horstmann and Markusen (1987, 1992), Markusen and Venables (1998, 2000) and Markusen (2002, ch. 4), who allowed for various endogenous market structures and different forms of imperfect competition. ${ }^{4}$

Since the 2000s, the most recent strand in the FDI literature that stresses the role of firm heterogeneity has been rapidly developing. This strand was initiated by Helpman et al. (2004), who studied the role of productivity in the choice between exporting and FDI. They generalized the monopolistic competition model with heterogeneous firms proposed by Melitz (2003) to demonstrate that only highly productive firms can enter foreign markets via FDI, while less productive enter via exporting and the least productive firms do not enter foreign markets at all. ${ }^{5}$ However, despite its great analyt-

\footnotetext{
${ }^{3}$ More recently, original Krugman (1983) model has been generalized and extended by Cieślik (2013) to allow for differences between countries in terms of their size and provide exact analytical solutions.

${ }^{4}$ More recent applications of oligopoly models to study interactions between FDI and trade include, inter alia, Sinha (2010), Collie (2011), Markusen and Stähler (2011), Cieślik and Ryan (2012), and Cieślik (2015).

${ }^{5}$ The predictions of this model were subject to a number of empirical tests including, inter alia, Girma et al. (2005), Greenaway and Kneller (2007), Cieślik and Ryan (2009). This strand in the literature has been recently surveyed by Antràs and Yeaple (2015).
} 
ical convenience, the monopolistic competition framework is not very helpful with regard to studying the interactions between competing firms as in this framework firms simply neglect the actions of their rivals.

In contrast to the aforementioned approaches, already Smith (1987) and Motta (1992) provided an alternative duopoly framework to study the choice between exporting and FDI in which entry decisions were made sequentially. In their framework the game between two competing firms unfolded as follows. In first stage, the foreign firm decided whether or not to establish a subsidiary in the foreign country. In the second stage, the indigenous firm from the host country decided whether to enter the market or not, and then the firms engaged in Cournot quantity competition. Their models assumed that entry decisions were made taking into account their effects on the subsequent quantity equilibrium. However, despite the fact that the theoretical studies by Smith (1987) and Motta (1992) provided descriptions of particular equilibriums that may emerge in their framework, they did not devote much attention to the proximity-concentration tradeoffs the constitute the central plank of the NTME.

Therefore, the main goal of the paper is to study the role of the proximity-concentration tradeoffs in the choice between exporting and FDI in the context of the Smith-Motta duopoly framework. The contribution of this paper to the literature is purely theoretical. In particular, we focus on a specific case of the model with a simple linear demand function to provide both formal quantitative and graphical characterization of each proximityconcentration tradeoff and the resulting equilibriums. In addition, we also summarize all possible equilibriums that may emerge depending on various participation constraints in a single table. This allows us to identify easily the necessary conditions for each equilibrium that may emerge as the outcomes of the Smith-Motta framework and hence derive a broader set of conclusions. Therefore, this paper aims to extend and complement the aforementioned studies.

The organization of this paper is as follows. First, we start with the description of the key assumptions of the Smith-Motta model. Then, we discuss payoffs and participation constraints associated with particular market entry strategies that result from the inverse linear demand function assumption. Subsequently, we discuss various proximity-concentration tradeoffs the foreign firm faces. Finally, we characterize six possible types of equilibriums that may emerge. In the last section, we summarize the main findings and provide directions for further research. 


\section{Research Methodology}

In this section we describe the methodology of the research and the main assumptions of the model. To study the choice between exporting and FDI we follow directly Smith (1987) and Motta (1992) and use a simple singlecountry Cournot oligopoly framework. In particular, we assume that there are only two firms in the domestic country that operate in a single industry: the domestic and foreign firms that are not capacity constrained. For simplicity, it is further assumed that the good produced by both firms is homogenous and produced under increasing returns to scale. Increasing returns to scale are modeled by assuming that the total cost function is:

$$
T C(x)=F+G+c x
$$

where: $F$ is the fixed sunk cost of developing the product, $G$ is the fixed sunk investment cost of entering the market (i.e. building a production plant), $c$ is the constant marginal cost of production and $x$ is output. It can be noted that the average cost of production declines with output as the fixed sunk costs are spread over a larger number of units: $A C(x)=(F+G) / x$ $+c$.

It is assumed that the marginal cost of production $c$ is exactly the same for both foreign and domestic firms. In addition, we assume that if the domestic firm decides to enter the market, it must incur both the fixed sunk cost of developing the product $F$ and the fixed sunk cost of building the plant $G$. However, we assume that the fixed sunk cost $F$ does not apply to the foreign firm, as it was incurred in the past when the foreign firm entered the market in its home country. Further, the fixed sunk cost $G$ applies to the foreign firm only when it enters the domestic country market via FDI. If the foreign firm decides to export instead of doing FDI it can save the fixed sunk cost, but it has to pay a higher marginal cost. We assume that in addition to the per unit cost of production $c$ the foreign firm has to pay the trade costs which consist of two components: transport cost $s$ and tariff $t$ which increase the marginal cost. The transport cost and the tariff are assumed to be exogenously given. 


\section{Andrzej Cieślik}

For simplicity, to be able to obtain explicit analytical solutions, we use a simple linear inverse demand function that relates price $P$ to total output $X$ supplied by both firms to the market: ${ }^{6}$

$$
P(X)=a-X,
$$

where $a>c$ is the market size in the domestic country. $X$ is the sum of output supplied to the market by both firms: $X=x_{F}+x_{D}$, where $x_{F}\left(x_{D}\right)$ denotes output supplied by the foreign (domestic) firm.

Figure 1. The extensive form of the game between the foreign and domestic firms

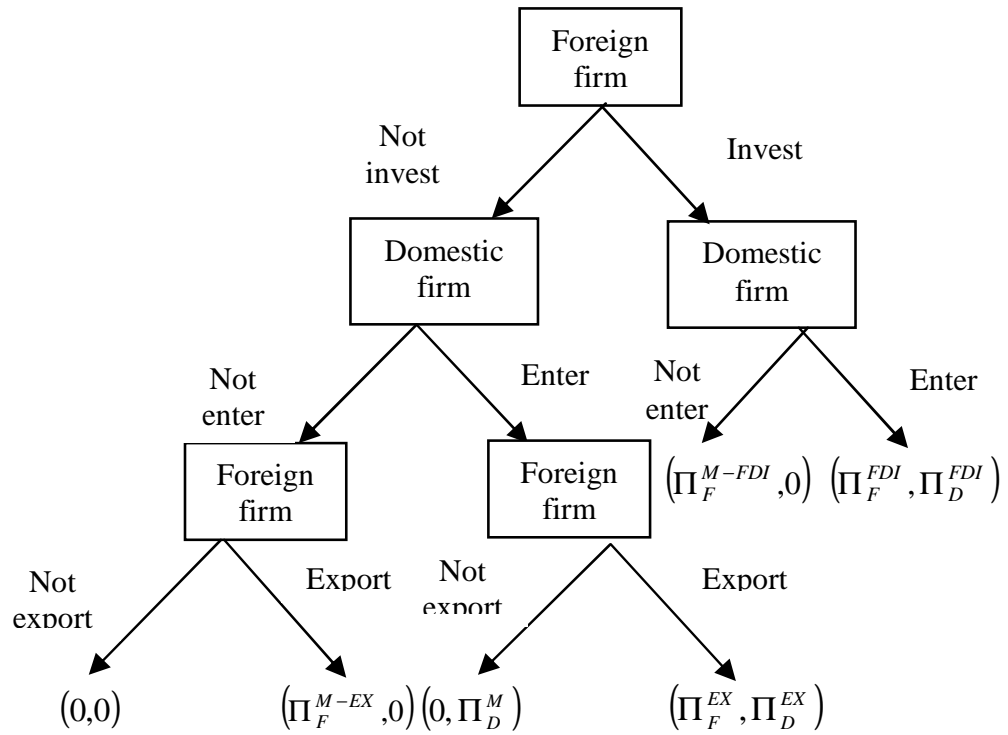

Source: own elaboration based on Motta (1992).

Following Motta (1992) the extensive form of the game between the foreign and domestic firms is illustrated in Figure 1, which shows the sequence of all the possible actions and outcomes for domestic and foreign

${ }^{6}$ The assumption of the linear demand function has become standard in the FDI literature and has been used in a large number of studies including, inter alia, Görg (2000), Sinha (2010), Dijkstra et al. (2011), Zajc Kejžar (2011), Cieślik and Ryan (2012), and Cieślik (2015). 
firms. ${ }^{7}$ Each line represents an action, and each box represents a decision point. The outcomes of actions are shown in parentheses, where the foreign firm's profits are listed first.

In the first stage of the game the foreign firm decides whether to do FDI and incur the fixed sunk cost $G$ of building the plant in the host country or not. Looking at this choice in the second stage of the game, the domestic firm decides whether to enter the market and pay the fixed sunk cost $F+G$ or not. If both firms incurred the sunk costs, they play a standard Cournot output game. In this case the foreign firm earns FDI duopoly profit $\Pi_{F}^{F D I}$, while the domestic firm $\Pi_{D}^{F D I}$. If the foreign firm builds the production capacity in the host country market while the domestic firm does not enter the market, the foreign firm captures the entire market and makes FDI monopoly profit $\Pi_{F}^{M-F D I}$.

If the foreign firm decided not to do FDI in the first stage of the game and the domestic firm entered the host country market in the second stage of the game, the foreign firm chooses whether to serve it via exporting and pay trade costs $s+t$ per unit of exports or not to sell in that market at all. If the foreign firm decides to export, a third stage of the game comes into play in which the two firms play the standard Cournot game. In this case, the foreign firm earns exporting duopoly profit $\Pi_{F}^{E X}$ and the domestic firm $\Pi_{D}^{E X}$. However, if the foreign firm decides not to export, the domestic firm becomes the monopolist and earns profit $\Pi_{D}^{M}$.

Finally, if the foreign firm decided not to do FDI in the first stage of the game, and the domestic firm decided not to enter the market in the second stage of the game, the foreign firm chooses again whether to export or not to sell in the host country market at all. If it exports, it becomes an exporting monopolist in that market and earns profit $\Pi_{F}^{M-E X}$. If it does not enter, then the demand in the host country is left unserved.

${ }^{7}$ It must be noted that the structure of the game proposed by Motta (1992) is different from Smith (1987). In particular, the time structure underlines different degrees of irreversibility involved in firms' decisions. A decision to export by the foreign firm or decision not to enter by the home firm is a decision that can be reversed once the rival firm has made its decision whereas the entry and foreign direct investment are the long-run decisions. Also the set of strategies available to the foreign firm is extended to allow for the option of not entering at all the market in the domestic country which was a priori excluded in Smith (1987). Therefore, the approach proposed by Motta (1992) can be treated as a generalization of Smith (1992). 


\section{Payoffs and Participation Constraints}

In this section we discuss the payoffs associated with particular entry strategies, and participation constraints that imply non-negative levels of profits for foreign and domestic firms. First, we consider the case when the fixed sunk market entry costs for the domestic firm $(F+G)$ are so high that the domestic firm decides not to enter the market in the domestic country, and the foreign firm becomes a monopolist in the domestic market and discuss two standard host market entry strategies: FDI and exporting of the foreign firm. Then, we discuss a more complex case when then foreign firm has to compete with the domestic firm in the Cournot manner.

\section{FDI monopoly}

If the foreign firm decides to serve the domestic market via FDI, it must incur the fixed sunk cost of building the plant $G$ in the domestic country and its profit function can be written as:

$$
\Pi_{F}^{M-F D I}=\left[a-X_{F}^{M-F D I}\right] X_{F}^{M-F D I}-c X_{F}^{M-F D I}-G
$$

Using the first order condition, we can obtain the FDI monopoly equilibrium output:

$$
X_{F}^{M-F D I}=\frac{a-c}{2}
$$

The equilibrium monopoly price in the domestic market can be determined by substituting the FDI monopoly equilibrium output of the foreign firm (4) into the inverse demand function (2), which yields:

$$
p_{F}^{M-F D I}=\frac{a+c}{2}
$$


Substituting equilibrium solutions for output (4) and price (5) into the profit function (3) yields the equilibrium monopoly profit from FDI for the foreign firm:

$$
\Pi_{F}^{M-F D I}=\left(\frac{a-c}{2}\right)^{2}-G=\left[X_{F}^{M-F D I}\right]^{2}-G
$$

The foreign firm enters the domestic country market via FDI only if its operating profit is bigger than the fixed cost of entry:

$$
G<\left(\frac{a-c}{2}\right)^{2}
$$

Exporting monopoly

If the foreign firm decides to serve the domestic market by exporting, its profit function can be written as:

$$
\Pi_{F}^{M-E X}=\left[a-X_{F}^{M-E X}\right] X_{F}^{M-E X}-(c+s+t) X_{F}^{M-E X}
$$

Using the first order condition, we can obtain the exporting monopoly equilibrium output:

$$
X_{F}^{M-E X}=\frac{a-c-s-t}{2}
$$

The equilibrium monopoly price in the domestic market can be determined by substituting the exporting monopoly equilibrium output of the foreign firm (9) into the inverse demand function (2) which yields:

$$
p_{F}^{M-E X}=\frac{a+c+s+t}{2}
$$


Substituting equilibrium solutions for output (9) and price (10) into the profit function (8) yields the equilibrium monopoly profit from exporting:

$$
\Pi_{F}^{M-E X}=\left(\frac{a-c-s-t}{2}\right)^{2}=\left[X_{F}^{M-E X}\right]^{2}
$$

The foreign firm enters the market in the domestic country via exporting only if its profit in that market is positive, which implies the following participation constraint:

$$
s+t<a-c
$$

Domestic monopoly

We also consider the autarky case when the domestic market entry costs are so high that the foreign firm cannot enter the market, and the domestic firm enjoys a monopoly power. In this case, the profit function of the domestic monopolist can be written as:

$$
\left.\Pi_{D}^{M}=\left[a-X_{D}^{M}\right)\right] X_{D}^{M}-c X_{D}^{M}-F-G
$$

Using the first order condition, we can determine the domestic monopoly equilibrium output:

$$
X_{D}^{M}=\frac{a-c}{2}
$$

The equilibrium monopoly price in the domestic market can be determined by substituting the equilibrium monopoly output (14) into the inverse demand function (2) which yields:

$$
p_{D}^{M}=\frac{a+c}{2}
$$


Substituting equilibrium solutions for output (14) and price (15) into the profit function (13), we obtain the equilibrium monopoly profit for the domestic firm:

$$
\Pi_{D}^{M}=\left(\frac{a-c}{2}\right)^{2}-F-G=\left[x_{D}^{M}\right]^{2}-F-G
$$

The domestic monopolist is active in the domestic market if the following market participation constraint is satisfied:

$$
F+G<\left(\frac{a-c}{2}\right)^{2}
$$

\section{FDI Cournot duopoly}

If foreign firm decides to enter the domestic market via FDI and the domestic firm decides to compete, we have the FDI Cournot duopoly problem. In this case, if the foreign firm enters the market in the host country and competes with the domestic firm, its profit function can be written as:

$$
\Pi_{F}^{F D I}=\left[a-\left(x_{F}^{F D I}+x_{D}^{F D I}\right)\right] x_{F}^{F D I}-c x_{F}^{F D I}-G
$$

In a similar way, we can write down the profit function of the domestic firm:

$$
\Pi_{D}^{F D I}=\left[a-\left(x_{F}^{F D I}+x_{D}^{F D I}\right)\right] x_{D}^{F D I}-c x_{D}^{F D I}-F-G
$$

Using the first order conditions for the domestic and foreign firms, the outputs supplied by both firms to the domestic market can be written as, respectively:

$$
\begin{aligned}
& x_{F}^{F D I}=\frac{a-c}{3} \\
& x_{D}^{F D I}=\frac{a-c}{3}
\end{aligned}
$$


We can note that the volumes of output supplied by the foreign and domestic firms to the host country market when the foreign firm enters via FDI and faces competition from the domestic firm are exactly the same.

The total equilibrium level of output supplied to the host-country market is the sum of outputs (20)-(21) supplied jointly by the foreign and domestic firms which can be written as:

$$
X^{F D I}=x_{D}^{F D I}+x_{F}^{F D I}=\frac{2(a-c)}{3}>X_{F}^{M}=X_{D}^{M}
$$

It can be easily noted that the total level of output supplied to the market is now bigger compared to the previously discussed monopoly FDI and domestic firm equilibriums due to competition between firm. As the equilibrium level of output is now bigger, the equilibrium price is lower. The equilibrium price in the domestic market can be determined by substituting the sum of output (22) into the inverse demand function (2) to obtain:

$$
p^{F D I}=\frac{a+2 c}{3}<p_{D}^{M}=p_{F}^{M-F D I}=\frac{a+c}{2}
$$

Using our solutions for the equilibrium quantities (20)-(21) and price (23) the total profits for the foreign and domestic firms can be written as, respectively:

$$
\begin{aligned}
& \Pi_{F}^{F D I}=\left(\frac{a-c}{3}\right)^{2}-G=\left[x_{F}^{F D I}\right]^{2}-G \\
& \Pi_{D}^{F D I}=\left(\frac{a-c}{3}\right)^{2}-F-G=\left[x_{D}^{F D I}\right]^{2}-F-G
\end{aligned}
$$

It can be noted that the operating profits of both firms are now lower compared to the FDI and domestic monopoly equilibriums as now firms have to compete with each other. Moreover, the overall profit of the foreign firm is bigger compared to the profit of the domestic firm as it has to pay a fixed market entry cost $F$ in addition to the fixed cost of building the plant $G$.

To ensure that both firms are active in the host-country market, we need to impose the market participation constraints stating that both firms have non-negative levels of equilibrium profits. These conditions require that 
operating profits in the domestic market must be bigger than the fixed costs. The participation constraint for the foreign firm requires that

$$
G<\left(\frac{a-c}{3}\right)^{2}
$$

The participation constraint for the domestic firm requires that

$$
F+G<\left(\frac{a-c}{3}\right)^{2}
$$

It can be noted that it is easier to satisfy the participation constraint for the foreign firm than for the domestic firm, hence if (27) is satisfied then also (26) is satisfied. If participation constraints are met, then both firms have non-negative profits and supply positive amounts of output to the domestic market.

\section{Exporting Cournot duopoly}

If the foreign firm decides to enter the domestic market via exporting and the domestic firm decides to compete, we have an exporting Cournot duopoly problem. In this case, the profit function of the foreign firm can be written as:

$$
\Pi_{F}^{E X}=\left[a-\left(x_{F}^{E X}+x_{D}^{E X}\right)\right] x_{F}^{E X}-(c+s+t) x_{F}^{E X}
$$

For the foreign firm exporting to the domestic market from the production facility located abroad implies a high marginal cost option due to the existence of transport costs $s$ and tariffs $t$. However, this strategy allows the foreign firm to save on the fixed cost of investment $G$.

In this case, the profit function for the domestic firm can be written as:

$$
\Pi_{D}^{E X}=\left[a-\left(x_{F}^{E X}+x_{D}^{E X}\right)\right] x_{D}^{E X}-c x_{D}^{E X}-F-G
$$

Using the first order conditions, we can determine the equilibrium levels of output supplied by the foreign and domestic firms to the domestic market, respectively: 


$$
\begin{aligned}
& x_{F}^{E X}=\frac{a-c-2(s+t)}{3} \\
& x_{D}^{E X}=\frac{a-c+(s+t)}{3}
\end{aligned}
$$

We can note that compared to FDI solutions now the equilibrium levels of output contain the transport cost and the tariff. As a result, the domestic firm's output is higher and the foreign firm's output is lower compared to the earlier case, when the foreign firm serves the domestic market via FDI. In the special case when trade is completely free, i.e. $s+t=0$ the output levels of both firms are the same as in the previous case.

The total equilibrium level of output supplied to the domestic market is the sum of outputs (30)-(31) supplied jointly by the foreign and domestic firms that equals:

$$
X^{E X}=x_{D}^{E X}+x_{F}^{E X}=\frac{2(a-c)-(s+t)}{3}<X^{F D I}
$$

It can be noted that the equilibrium level of the total output supplied to the domestic market when the foreign firm enters this market via exporting is smaller compared to compared to the equilibrium level of output in the case when it enters via FDI (18) due to the inefficiencies associated with the existence of the transport cost and the tariff.

The equilibrium price in the domestic market can be determined by substituting the sum of output (32) into the inverse demand function (2), which yields:

$$
p^{E X}=\frac{a+2 c+s+t}{3}>p^{F D I}
$$

It can be noted that the price in the exporting Cournot equilibrium will always be higher compared to the FDI Cournot equilibrium due to the technical inefficiency associated with the existence of the trade cost.

Using our solutions for the equilibrium quantities (30)-(31) and the equilibrium price (33), we can determine the equilibrium profits for the domestic and foreign firms, respectively:

$$
\Pi_{F}^{E X}=\left(\frac{a-c-2(s+t)}{3}\right)^{2}=\left[x_{F}^{E X}\right]^{2}
$$




$$
\begin{aligned}
& \Pi_{D}^{E X}=\left(\frac{a-c+s+t}{3}\right)^{2}-F-G>\Pi_{D}^{F D I} \\
& =\left[x_{D}^{E X}\right]^{2}-F-G
\end{aligned}
$$

It can be noted that for the domestic firm it is always better if the foreign firm enters the domestic market via exporting rather than via FDI. The domestic firm's profit is higher when the foreign firm exports than when it enters via FDI for two reasons: i) the domestic firm's larger sales, ii) a higher equilibrium price. Hence, for the domestic firm $\Pi_{D}^{E X}>\Pi_{D}^{F D I}$ is always satisfied.

However, for the foreign firm such a simple generalization cannot be made. Although the operating profit associated with FDI is higher than the exporting profit, the fixed cost of investment $G$ can make the foreign firm's overall profit of FDI lower than the profit from exporting. Hence, whether the profit from exporting is bigger or smaller compared to the profit from FDI for the foreign firm depends on the interplay between the trade and investment costs $(s+t$ and $G)$. This 'proximity-concentration' tradeoff will be studied in the next section.

To ensure both firms are active in the domestic market, we must impose market participation constraints on the domestic and foreign firms stating that they must have non-negative levels of profits. The participation constraint for the foreign firm requires that:

$$
2(s+t)<a-c
$$

Similarly, the participation constraint for the domestic firm requires that:

$$
F+G<\left(\frac{a-c+s+t}{3}\right)^{2}
$$

It can be noted that now it is easier for the domestic firm to satisfy the participation constraint, as it has a higher operating profit compared to the previous case when the foreign firm entered the domestic market via FDI. If both (36) and (37) are satisfied, then both firms have non-negative profits and supply positive amounts of output to the domestic market. 


\section{Proximity-concentration Tradeoffs}

In this section, we discuss various proximity-concentration tradeoffs the foreign firm faces. First, we discuss the tradeoff between FDI monopoly and exporting monopoly for the foreign firm, then the tradeoff between FDI and exporting under duopoly, and finally we discuss the tradeoff between FDI monopoly and exporting duopoly.

\section{Tradeoff between FDI monopoly and exporting monopoly}

To study the tradeoff between FDI monopoly and exporting monopoly, we compare profits of the foreign firm for FDI monopoly (6) and exporting monopoly (11). The profits of the foreign firm from FDI monopoly and exporting monopoly are equal when:

$$
G=\frac{2(a-c)(s+t)-(s+t)^{2}}{4}
$$

If the fixed cost of investment $\mathrm{G}$ is bigger (smaller) than the threshold value (38), the foreign firm prefers exporting (FDI) monopoly to FDI (exporting) monopoly.

\section{Tradeoff between FDI duopoly and exporting duopoly}

To analyze the tradeoff between FDI duopoly and exporting, duopoly we compare profits of the foreign firm from FDI duopoly (24) and exporting duopoly (34). The profits of the foreign firm from exporting duopoly and FDI duopoly are equal when:

$$
G=\frac{4(a-c)(s+t)-4(s+t)^{2}}{9}
$$

If $\mathrm{G}$ is bigger (smaller) than the threshold value (39), then exporting (FDI) is the preferred entry strategy for the foreign firm. It can be noted that the threshold value of the fixed cost (39) is bigger than (38). This means that increased competition in the domestic market makes the entry of the foreign firm via FDI less likely. Moreover, FDI can always be a preferred to exporting for certain combinations of model parameters such as the high trade cost and the low fixed cost of investment. Similarly, exporting can always be a preferred option to FDI for certain combinations of 
model parameters, such as the low trade cost and the high fixed cost of investment.

\section{Tradeoff between FDI monopoly and exporting duopoly}

To analyze the tradeoff between FDI monopoly and exporting duopoly, we compare profits of foreign firm from FDI monopoly (6) and exporting duopoly (35). The profits of the foreign firm from FDI monopoly and exporting duopoly are equal when:

$$
G=\frac{5(a-c)^{2}}{36}+\frac{4(a-c)(s+t)-4(s+t)^{2}}{9}
$$

If the fixed cost of investment $G$ is bigger (smaller) than the threshold value (40), then exporting (FDI) is the preferred entry strategy for the foreign firm. In addition, FDI can always be a preferred to exporting for certain combinations of model parameters, such as the high trade cost and the low fixed cost of investment. Similarly, exporting can always be preferred to FDI for certain combinations of model parameters, such as the low trade cost and the high fixed cost of investment.

\section{Equilibriums}

In this model six possible equilibriums may emerge, depending on various combinations of the key parameters of models: a FDI monopoly equilibrium, an exporting monopoly equilibrium, a domestic monopoly equilibrium, a FDI duopoly equilibrium, an exporting duopoly equilibrium, and a noentry equilibrium.

To identify those equilibriums, we distinguish between three types of trade and investment costs for the foreign firm: low (i.e. $2(s+t)<a-c$ and $G<\left(\frac{a-c}{3}\right)^{2}$, respectively), high (i.e. $a-c<2(s+t)<2(a-c)$ and $\left(\frac{a-c}{3}\right)^{2}<G<\left(\frac{a-c}{2}\right)^{2}, \quad$ respectively), and prohibitively high (i.e. $(s+t)>a-c$ and $G>\left(\frac{a-c}{2}\right)^{2}$, respectively). When low costs occur the foreign firm is able to enter the host market and compete with the domestic firm. When high costs occur the foreign firm is able to enter the host mar- 
ket only if the domestic firm does not enter. Finally, when these costs are prohibitively high, the foreign firm does not enter at all.

We also distinguish four different ranges of the fixed sunk costs for the domestic firm: low $\quad$ (i.e. $\left.F+G<\left(\frac{a-c}{3}\right)^{2}\right)$, high $\quad$ (i.e., $\left.\left(\frac{a-c}{3}\right)^{2}<F+G<\left(\frac{a-c+s+t}{3}\right)^{2}\right), \quad$ very $\quad$ high $\quad$ (i.e. $\left.\left(\frac{a-c}{2}\right)^{2}>F+G>\left(\frac{a-c+s+t}{3}\right)^{2}\right) \quad$ and prohibitively high (i.e. $F+G>\left(\frac{a-c}{2}\right)^{2}$ ). When the low fixed costs occur the domestic firm is able to compete with the foreign firm irrespectively of its entry strategy. When the high fixed costs occur then the domestic firm is able to compete with the foreign firm only when it exports. When the fixed costs are very high, the domestic firm can enter only when the foreign firm does not enter. Finally, when the costs are prohibitively high, the domestic firm does not enter, irrespectively of the decision of the foreign firm.

We start with the discussion of the benchmark equilibriums in which the domestic firm decides not to enter the market, and the foreign firm becomes a monopolist serving the host country market either via FDI or via exporting. Then, we describe FDI and exporting duopoly equilibriums. Finally, we discuss the domestic monopoly and no entry equilibriums.

The FDI monopoly equilibriums may occur when the domestic firm is unable to compete with the foreign firm, irrespectively of its entry strategy (i.e. when the fixed sunk costs are very high), or only when it enters via FDI (i.e. when the fixed sunk costs are high) or when the domestic firm does not enter the market at all (i.e. the fixed sunk costs are prohibitively high).

If the fixed sunk costs are high, the domestic firm is unable to compete with the foreign firm only when it enters via FDI, and both trade and investment costs are low, then there is no tradeoff. This is because the foreign firm always chooses FDI to capture the entire market in the host country instead of having to share the market with the domestic firm when exporting. However, if the trade costs are low, while the investment cost is high, then the foreign firm faces the tradeoff between becoming a monopolist when it enters via FDI and sharing the market with the local firm when it exports. Hence, it chooses FDI and becomes the monopolist only if the investment cost is below the threshold level (40). Moreover, the foreign firm chooses FDI and becomes the monopolist when: i) the trade costs are 
high and the investment cost is low, ii) both trade and investment costs are high, iii) the trade costs are prohibitively high and the investment cost is low, and iv) the trade cost are prohibitively high and the investment cost is high.

If the fixed sunk costs are very high the domestic firm is unable to compete with the foreign firm, irrespectively of its entry strategy and both trade and investment cost are low, then the foreign firm faces the tradeoff between FDI and exporting. It chooses FDI only if the investment cost is below the threshold level (38). Similarly, if the trade costs are low and the investment cost is high, or when both trade and investment costs are high, the foreign firm chooses FDI only if the investment cost is below the threshold level (38). Moreover, the foreign firm chooses FDI and becomes the monopolist when: i) the trade costs are high and the investment cost is low, ii) the trade costs are prohibitively high and the investment cost is low, and iii) the trade cost are prohibitively high and the investment cost is high.

Also, if the fixed sunk costs are prohibitively high, the domestic firm is unable to survive in the market even as a monopolist and both trade and investment cost are low, then foreign firm faces the tradeoff between FDI and exporting. It chooses FDI only if the investment cost is below the threshold level (38). If the trade costs are low and the investment cost is high or when both trade and investment costs are high, the foreign firm chooses FDI only if the investment cost is below the threshold level (38). In addition, the foreign firm chooses FDI and becomes the monopolist when: i) the trade costs are high and the investment cost is low, ii) the trade costs are prohibitively high and the investment cost is low, and iii) the trade cost are prohibitively high and the investment cost is high.

Exporting monopoly equilibriums may occur only when the domestic firm is unable to compete with the foreign firm, irrespectively of its entry strategy. This occurs when the fixed sunk costs for the domestic firm are very high or prohibitively high. If both trade and investment cost are low, then the foreign firm faces the tradeoff between FDI and exporting. It chooses exporting only if the investment cost is above the threshold level (38). Similarly, if the trade costs are low and the investment cost is high, or when both the trade and investment costs are high, the foreign firm chooses exporting only if the investment cost is above the threshold level (38). In addition, the foreign firm chooses exporting and becomes the monopolist when: i) the trade costs are low and the investment cost is prohibitively high, and ii) the trade costs are high and the investment cost is prohibitively high.

Next, we discuss the duopoly equilibriums in which the domestic firm decides to enter the market and compete with the foreign firm. The duopoly 
FDI equilibriums occur only when the fixed sunk costs are low and domestic firm is able to compete with the foreign firm, irrespectively of its entry strategy. If both trade and investment costs are low the foreign firm faces a tradeoff between FDI and exporting. It chooses FDI only if the investment cost is below the threshold level (39). Moreover, the foreign firm always chooses FDI when: i) the trade costs are high and the investment cost is low, and ii) the trade costs are prohibitively high and the investment cost is low.

The duopoly exporting equilibriums occur when the domestic firm is able to compete with the foreign firm, irrespectively of its entry strategy, or only when it exports. If the fixed sunk costs are low, and the domestic firm is able to compete with the foreign firm irrespectively of its entry strategy, and both trade and investment costs are low, the foreign firm faces a tradeoff between FDI and exporting. It chooses exporting only if the investment cost is above the threshold level (39). In addition, the foreign firm always chooses exporting when: i) the trade costs are low and the investment cost is high, and ii) the trade costs are low and the investment cost is prohibitively high.

If the fixed sunk costs are high, and the domestic firm is able to compete with the foreign firm only when it exports, and the trade costs are low while the investment cost is high, the foreign firm faces a tradeoff between becoming a monopolist when it enters via FDI and sharing the market with the local firm when it exports. It chooses exporting only if the investment cost is above the threshold level (40). Moreover, the exporting duopoly equilibrium occurs when the trade costs are low and the investment cost is prohibitively high.

Finally, the domestic monopoly equilibrium occurs if the fixed sunk costs are low, and the domestic firm is able to compete with the foreign firm irrespectively of its entry strategy, when: i) both trade and investment costs are high, ii) the trade costs are high and the investment cost is prohibitively high, iii) the trade costs are prohibitively high and the investment cost is high, and iv) both trade and investment costs are prohibitively high. Similarly, the domestic monopoly equilibrium occurs if the fixed sunk costs are high, and the domestic firm is able to compete with the foreign firm, irrespectively of its entry strategy, when: i) the trade costs are high and the investment cost is prohibitively high, and ii) both trade and investment costs are prohibitively high. If the fixed sunk costs for the domestic firm are very high, the domestic monopoly equilibrium occurs only if both trade and investment costs for the foreign firm are prohibitively high. The no entry equilibrium occurs only when the fixed sunk costs for the domestic 
firm are prohibitively high, and both trade and investment costs for the foreign firm are prohibitively high.

Figures 2-5 and Table 1 provide the summary of the results for different cases of ranges of participation constraints for domestic and foreign firms as well as tradeoffs between FDI and exporting.

Figure 2. Possible equilibriums when the fixed costs for the domestic firm are low, (i.e. $F+G<\left(\frac{a-c}{3}\right)^{2}$ )

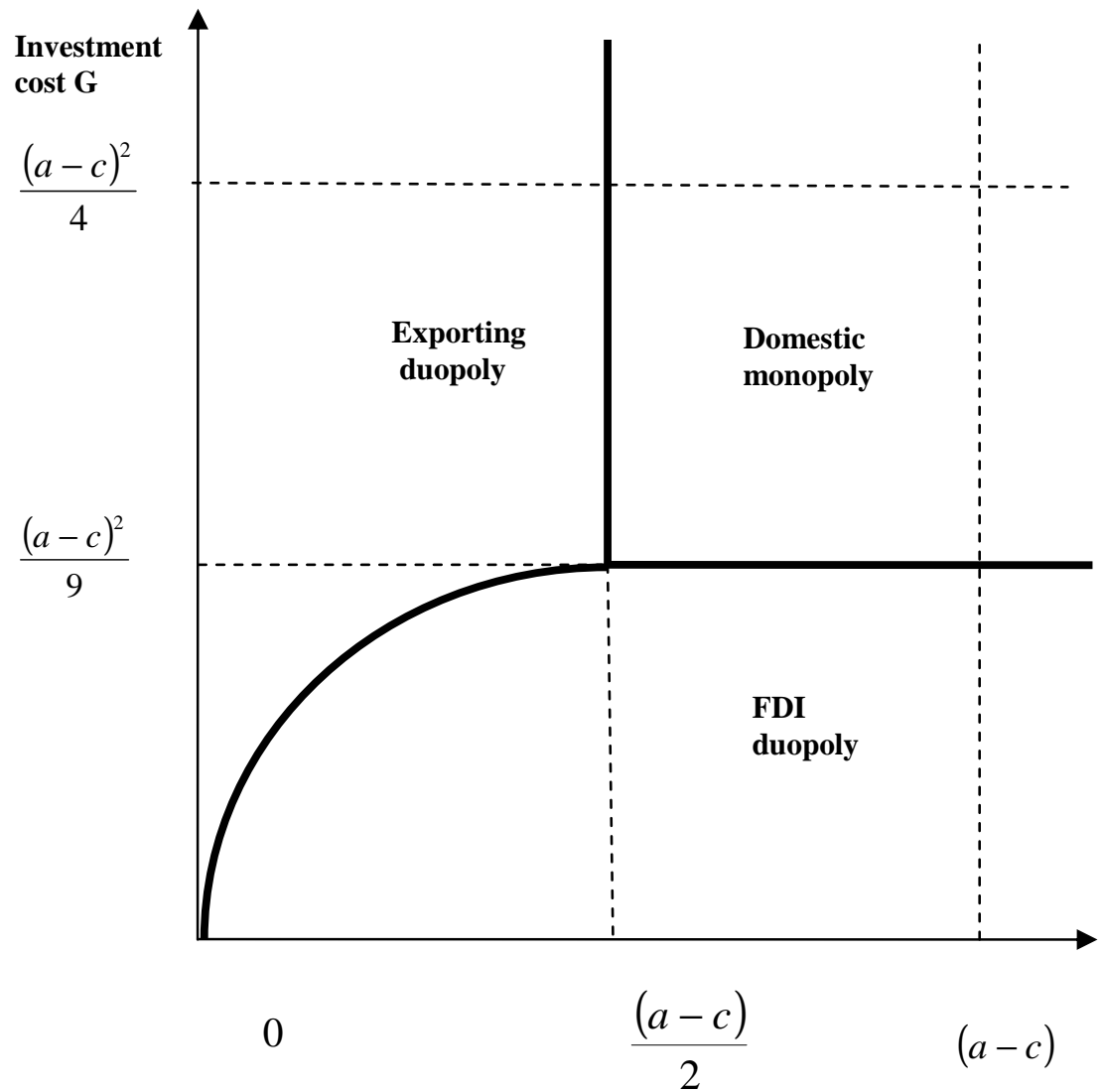

Trade costs $s+t$

Source: own elaboration. 
Figure 3. Possible equilibriums when the fixed costs for the domestic firm are high, (i.e., $\left(\frac{a-c}{3}\right)^{2}<F+G<\left(\frac{a-c+s+t}{2}\right)^{2}$ )

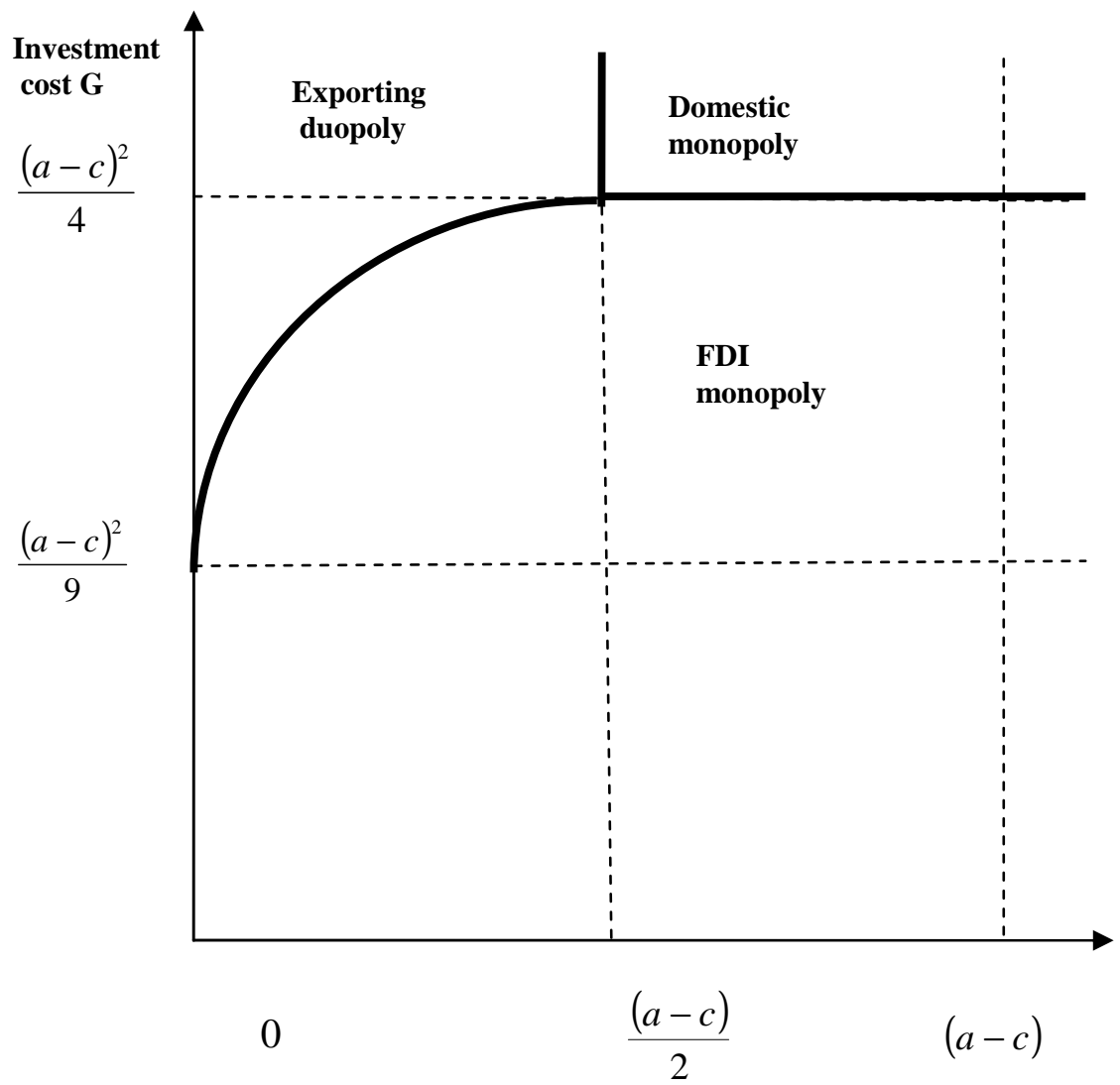

Trade costs s+t

Source: own elaboration. 
Figure 4. Possible equilibriums when the fixed costs for the domestic firm are very high, (i.e. $\left(\frac{a-c}{2}\right)^{2}>F+G>\left(\frac{a-c+s+t}{2}\right)^{2}$ )

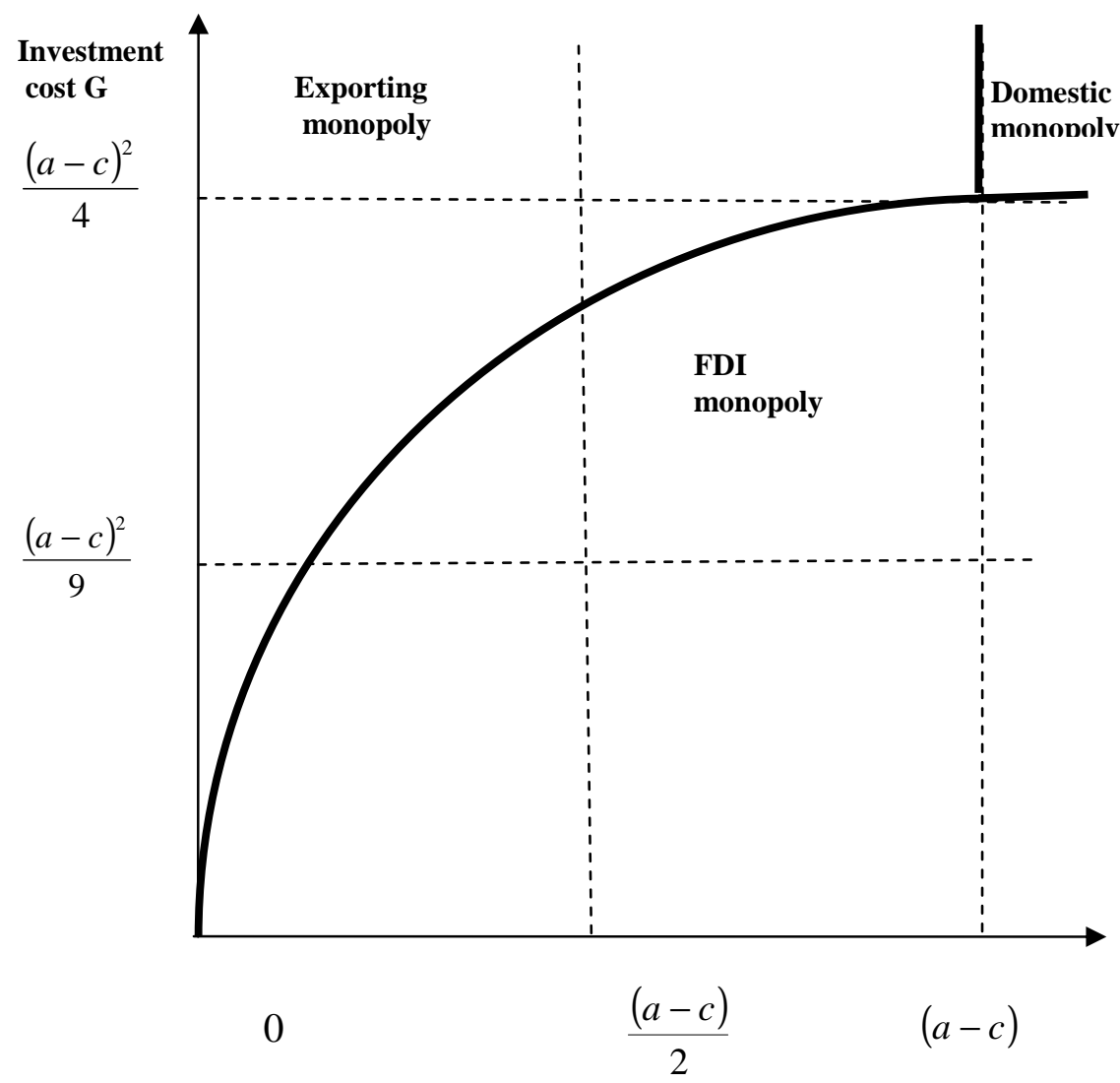

Trade costs $s+t$

Source: own elaboration. 


\section{Andrzej Cieślik}

Figure 5. Possible equilibriums when the fixed costs for the domestic firm are prohibitive, (i.e. $F+G>\left(\frac{a-c}{2}\right)^{2}$ )

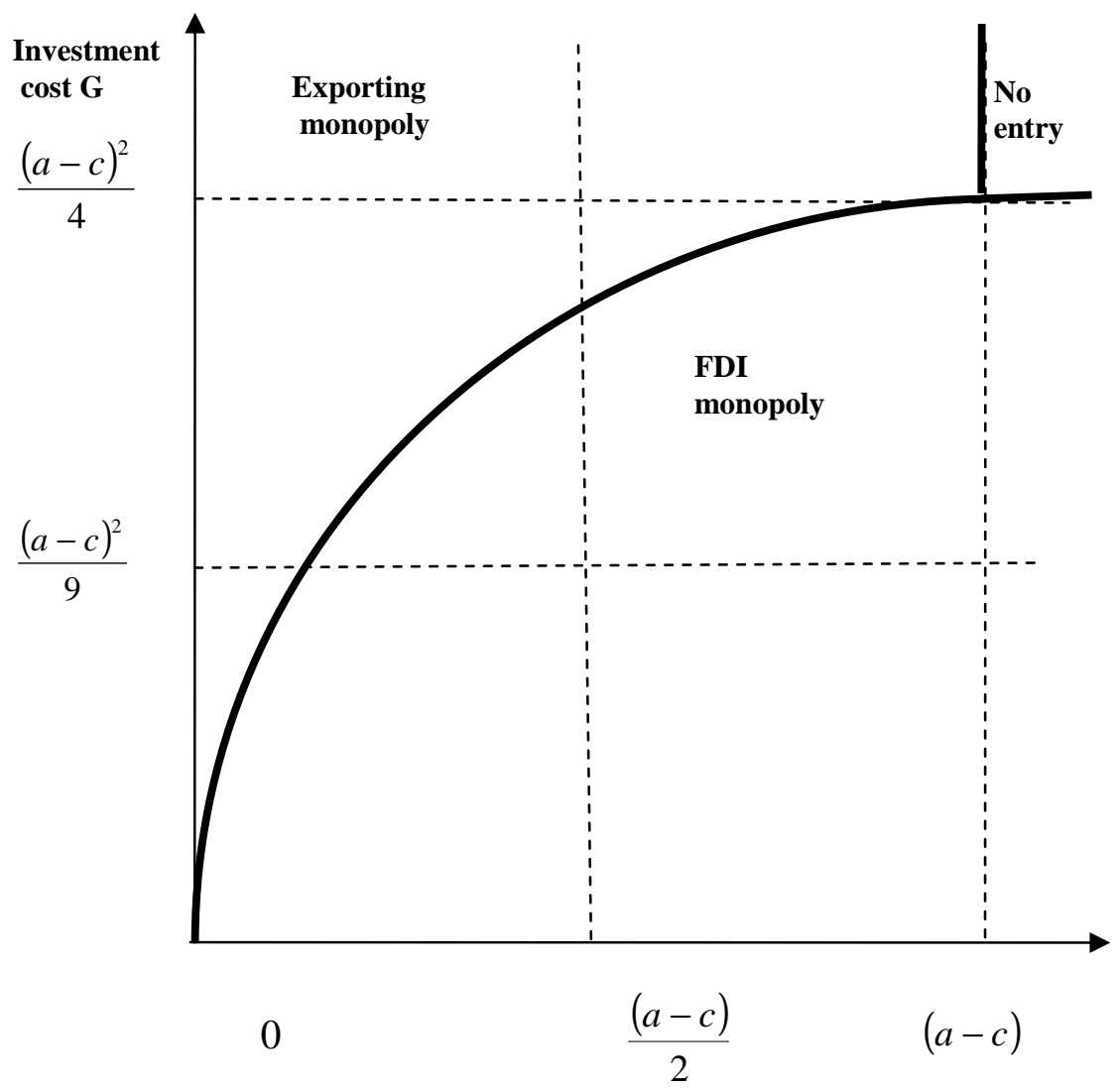

Trade costs $s+t$

Source: own elaboration. 
Table 1. Monopoly and Cournot Duopoly Equilibriums

\begin{tabular}{|c|c|c|}
\hline $\begin{array}{l}\text { Domestic firm } \\
\text { Foreign firm }\end{array}$ & $F+G<\left(\frac{a-c}{3}\right)^{2}$ & $\left(\frac{a-c}{3}\right)^{2}<F+G<\left(\frac{a-c+s+t}{3}\right)^{2}$ \\
\hline $\begin{array}{l}2(s+t)<a-c \\
\quad \text { and } \\
G<\left(\frac{a-c}{3}\right)^{2}\end{array}$ & $\begin{array}{c}\text { FDI duopoly if } \\
G<\frac{4(a-c)(s+t)-4(s+t)^{2}}{9} \\
\begin{array}{c}\text { Exporting duopoly if } \\
G>\frac{4(a-c)(s+t)-4(s+t)^{2}}{9}\end{array}\end{array}$ & FDI monopoly \\
\hline $\begin{array}{c}2(s+t)<a-c \\
\text { and } \\
\left(\frac{a-c}{3}\right)^{2}<G<\left(\frac{a-c}{2}\right)^{2}\end{array}$ & Exporting duopoly & $\begin{array}{c}\text { FDI monopoly if } \\
G<\frac{5(a-c)^{2}}{36}+\frac{4(a-c)(s+t)-4(s+t}{9} \\
\quad \text { Exporting duopoly if } \\
G>\frac{5(a-c)^{2}}{36}+\frac{4(a-c)(s+t)-4(s+t)}{9}\end{array}$ \\
\hline $\begin{array}{c}a-c<2(s+t)<2(a-c) \\
\quad \text { and } \\
G<\left(\frac{a-c}{3}\right)^{2}\end{array}$ & FDI duopoly & FDI monopoly \\
\hline $\begin{array}{c}a-c<2(s+t)<2(a-c) \\
\text { and } \\
\left(\frac{a-c}{3}\right)^{2}<G<\left(\frac{a-c}{2}\right)^{2}\end{array}$ & Domestic monopoly & FDI monopoly \\
\hline $\begin{array}{c}2(s+t)<a-c \\
\text { and } \\
G>\left(\frac{a-c}{2}\right)^{2}\end{array}$ & Exporting duopoly & Exporting duopoly \\
\hline $\begin{array}{c}a-c<2(s+t)<2(a-c) \\
\quad \text { and } \\
G>\left(\frac{a-c}{2}\right)^{2}\end{array}$ & Domestic monopoly & Domestic monopoly \\
\hline $\begin{array}{l}\quad(s+t)>a-c \\
\quad \text { and } \\
G<\left(\frac{a-c}{3}\right)^{2}\end{array}$ & FDI duopoly & FDI monopoly \\
\hline $\begin{array}{c}(s+t)>a-c \\
\text { and } \\
\left(\frac{a-c}{3}\right)^{2}<G<\left(\frac{a-c}{2}\right)^{2}\end{array}$ & Domestic monopoly & FDI monopoly \\
\hline $\begin{array}{c}(s+t)>a-c \\
\quad \text { and } \\
G>\left(\frac{a-c}{2}\right)^{2}\end{array}$ & Domestic monopoly & Domestic monopoly \\
\hline
\end{tabular}




\section{Andrzej Cieślik}

Table 1 continued

Domestic firm
Foreign firm

$$
\text { FDI monopoly if }
$$

FDI monopoly if

\begin{tabular}{|c|c|c|}
\hline $\begin{array}{c}2(s+t)<a-c \\
\quad \text { and }\end{array}$ & $G<\frac{2(a-c)(s+t)-(s+t)^{2}}{4}$ & $G<\frac{2(a-c)(s+t)-(s+t)^{2}}{4}$ \\
\hline$G$ & $\begin{array}{c}\text { Exporting monopoly if } \\
G>\frac{2(a-c)(s+t)-(s+t)^{2}}{4}\end{array}$ & $\begin{array}{c}\text { Exporting monopoly if } \\
G>\frac{2(a-c)(s+t)-(s+t)^{2}}{4}\end{array}$ \\
\hline $\begin{array}{c}2(s+t)<a-c \\
\text { and } \\
\left(\frac{a-c}{\underline{a}}\right)^{2}<G<\left(\frac{a-c}{c}\right)^{2}\end{array}$ & $\begin{array}{c}\text { FDI monopoly if } \\
G<\frac{2(a-c)(s+t)-(s+t)^{2}}{4}\end{array}$ & $\begin{array}{c}\text { FDI monopoly if } \\
G<\frac{2(a-c)(s+t)-(s+t)^{2}}{4}\end{array}$ \\
\hline 3$)-(2)$ & $\begin{array}{c}\text { Exporting monopoly if } \\
G>\frac{2(a-c)(s+t)-(s+t)^{2}}{4}\end{array}$ & $\begin{array}{c}\text { Exporting monopoly if } \\
G>\frac{2(a-c)(s+t)-(s+t)^{2}}{4}\end{array}$ \\
\hline $\begin{array}{c}a-c<2(s+t)<2(a-c) \\
\text { and } \\
G<\left(\frac{a-c}{3}\right)^{2}\end{array}$ & FDI monopoly & FDI monopoly \\
\hline $\begin{array}{c}a-c<2(s+t)<2(a-c) \\
\text { and } \\
\left(\frac{a-c}{3}\right)^{2}<G<\left(\frac{a-c}{2}\right)^{2}\end{array}$ & $\begin{array}{c}\text { FDI monopoly if } \\
G<\frac{2(a-c)(s+t)-(s+t)^{2}}{4}\end{array}$ & $\begin{array}{c}\text { FDI monopoly if } \\
G<\frac{2(a-c)(s+t)-(s+t)^{2}}{4}\end{array}$ \\
\hline & $\begin{array}{c}\text { Exporting monopoly if } \\
G>\frac{2(a-c)(s+t)-(s+t)^{2}}{4}\end{array}$ & $\begin{array}{c}\text { Exporting monopoly if } \\
G>\frac{2(a-c)(s+t)-(s+t)^{2}}{4}\end{array}$ \\
\hline $\begin{array}{c}2(s+t)<a-c \\
\quad \text { and } \\
G>\left(\frac{a-c}{2}\right)^{2}\end{array}$ & Exporting monopoly & Exporting monopoly \\
\hline $\begin{array}{c}-c<2(s+t)<2(a-c) \\
\text { and } \\
G>\left(\frac{a-c}{2}\right)^{2}\end{array}$ & Exporting monopoly & Exporting monopoly \\
\hline $\begin{array}{c}(s+t)>a-c \\
\quad \text { and } \\
G<\left(\frac{a-c}{3}\right)^{2}\end{array}$ & FDI monopoly & FDI monopoly \\
\hline
\end{tabular}


Table 1 continued

\begin{tabular}{ccc}
\hline $\begin{array}{c}(s+t)>a-c \\
\text { and }\end{array}$ & FDI monopoly & FDI monopoly \\
\hline$\left(\frac{a-c}{3}\right)^{2}<G<\left(\frac{a-c}{2}\right)^{2}$ & & \\
\hline $\begin{array}{c}(s+t)>a-c \\
\text { and }\end{array}$ & Domestic monopoly & No entry \\
$G>\left(\frac{a-c}{2}\right)^{2}$ & & \\
\hline
\end{tabular}

Source: own elaboration.

\section{Conclusions}

In this paper we have investigated the role of the proximity-concentration trade-off in the choice between exporting and FDI in the context of the Smith-Motta duopoly framework. First, we identified the conditions necessary for exporting and FDI, depending on the trade costs and the cost of foreign direct investment. Then, we demonstrated that six types of possible equilibriums might emerge depending on various combinations of the parameters of the model: the monopoly FDI equilibrium, the monopoly exporting equilibrium, the domestic monopoly equilibrium, the FDI duopoly equilibrium, the exporting duopoly equilibrium and no entry equilibrium.

Due to the space constraints, the theoretical framework employed in this paper was, however, based on very specific assumptions. Hence, there are still some possibilities to extend the baseline model. In particular, it was assumed for simplicity that the demand function was linear. Therefore, in future studies it would be useful to investigate whether the theoretical findings reported in this paper generalize to other demand functions such as, for example, iso-elastic demand functions derived from CES utility.

Moreover, it was assumed that the foreign firm moved first and the local firm followed. However, very often multinational enterprises, while making their foreign investment decisions, must be confronted with the local incumbents that operate already in the host country markets prior to the arrival of the MNEs. Therefore, it would be also useful to consider in future studies the situation when the local firm enjoys the first-mover advantage. 
In addition, it was assumed that both firms were equally productive and not capacity constrained. Therefore, it would be useful to relax these assumptions in future studies as well. Finally, in this paper we did not study the antitrust policy and welfare implications of particular equilibriums that could be potentially considered in future studies.

\section{References}

Antràs, P., \& Yeaple S. R., (2015). Multinational Firms and the Structure of International Trade. In E. Helpman, K. Rogoff, \& G. Gopinath (Eds.). Handbook of International Economics. Amsterdam: Elsevier.

Barba Navaretti, G., \& Venables A. (2004). Multinational Firms in the World Economy. Princeton: Princeton University Press.

Caves, R. (2007). Multinational Enterprise and Economic Analysis. Cambridge: Cambridge University Press.

Cieślik, A. (2013). Horizontally-Integrated MNE and Plant Heterogeneity. Bank $i$ Kredyt, 44(6).

Cieślik, A. (2015). North-North FDI, Exporting and the First Mover Advantage. Bank i Kredyt, 46(2).

Cieślik, A. (2015). Imperfect Competition, Productivity Differences and Proximity-Concentration Trade-Offs. Ekonomia. Rynek, Gospodarka, Spoteczeństwo, 40.

Cieślik, A. \& Ryan M. (2009). Firm Heterogeneity, Foreign Market Entry Mode and Ownership Choice. Japan and the World Economy, 21(3). DOI: http://dx.doi.org/10.1016/j.japwor.2008.07.001.

Cieślik, A. \& Ryan M. (2012). Productivity Differences and Foreign Market Entry in an Oligopolistic Industry. Open Economies Review, 23(3). DOI: http://dx.doi.org/10.1007/s11079-011-9204-6.

Collie, D. R. (2011). Multilateral Trade Liberalization, Foreign Direct Investment and the Volume of World Trade. Economics Letters, 113.

Copithorne, L. (1971). International Corporate Transfer Prices and Government Policy. Canadian Journal of Economics, 4(3). DOI: http://dx.doi.org/10.2307/ 133778.

Dijkstra, B. R., Mathew, A. J. \& Mukherjee, A. (2011). Environmental regulation: An Incentive for Foreign Direct Investment. Review of International Economics, 19(3).

Girma, S., Kneller, R., \& Pisu, M. (2005). Exports versus FDI: An Empirical Test. Review of World Economics, 141(2).

Görg,, H. (2000). Analysing Foreign Market Entry: the Choice between Greenfield Investment and Acquisitions. Journal of Economic Studies, 27.

Greenaway, D., Kneller R., (2007). Firm Heterogeneity, Exporting and Foreign Direct Investment. Economic Journal, 117(517). DOI: http://dx.doi.org/10 $.1111 / \mathrm{j} .1468-0297.2007 .02018 . \mathrm{x}$. 
Helpman, E., Melitz M., \& Yeaple S. (2004). Export versus FDI with Heterogeneous Firms. American Economic Review, 94(1). DOI: http://dx.doi.org/10 $.1257 / 000282804322970814$.

Hirsch, S. (1976). An International Trade and Investment Theory of the Firm. $O x$ ford Economic Papers, 28(2).

Horst, T. (1971). The Theory of the Multinational Firm: Optimal Behavior under Different Tariff and Tax Rules. Journal of Political Economy, 79(5). DOI: http://dx.doi.org/10.1086/259814.

Horstmann, I., \& Markusen J. (1987). Strategic Investments and the Development of Multinationals. International Economic Review, 28(1). DOI: http://dx.doi.org/10.2307/2526862

Horstmann, I., \& Markusen J. (1992). Endogenous Market Structure in International Trade (Natura Facit Saltum). Journal of International Economics, 32(12). DOI: http://dx.doi.org/10.1016/0022-1996(92)90038-L

Krugman, P. (1979). Increasing Returns, Monopolistic Competition, and International Trade. Journal of International Economics, 9(4). DOI: http://dx.doi.org/10.1016/0022-1996(79)90017-5

Krugman, P. (1980). Scale Economies, Product Differentiation and the Pattern of Trade. American Economic Review, 70(5).

Krugman, P. (1983). The 'New Theories' of International Trade and Multinational Enterprise. In D. B. Audretsch \& Ch. P. Kindleberger (Eds.). The Multinational Corporation in the 1980s. Cambridge MA: MIT Press.

Markusen, J. R. (1984). Multinationals, Multi-plant Economies and the Gains From trade. Journal of International Economics, 16(3-4). DOI: http://dx.doi.org/10.1016/S0022-1996(84)80001-X.

Markusen, J. R. (2002). Multinational Firms and the Theory of International Trade. Cambridge MA: MIT Press.

Markusen, J. R., \& Stähler F. (2011). Endogenous Market Structure and Foreign Market Entry. Review of World Economics, 147(2). DOI: http://dx.doi.org/10. 1007/s10290-010-0085-3.

Markusen, J. R., \& Venables A. J. (1998). Multinational Firms and the New Trade Theory. Journal of International Economics, 46(2). DOI: http://dx.doi.org/10. 1016/S0022-1996(97)00052-4.

Markusen, J. R., \& Venables A. J. (2000). The Theory of Endowment, IntraIndustry and Multinational Trade. Journal of International Economics, 52(2). DOI: http://dx.doi.org/10.1016/S0022-1996(99)00055-0

Melitz, M. (2003). The Impact of Trade on Intra-Industry Reallocations and Aggregate Industry Productivity. Econometrica 71(6). DOI: http://dx.doi.org/10. $1111 / 1468-0262.00467$.

Motta, M. (1992). Multinational Firms and the Tariff Jumping Argument. European Economic Review, 36(8). DOI: http://dx.doi.org/10.1016/0014-2921(92) 90006-I.

Mundell, R. (1957). International Trade and Factor Mobility. American Economic Review, 47(3). 
Sinha, U. B. (2010). Strategic Licensing, Exports, FDI, and Host Country Welfare. Oxford Economic Papers, 62(1). DOI: http://dx.doi.org/10.1093/oep/gpp014.

Smith, A. (1987). Strategic Investment, Multinational Corporations and Trade Policy. European Economic Review, 31(1-2). DOI: http://dx.doi.org/10.1016 10014-2921(87)90018-3

Zajc Kejžar, K. (2011). Does Foreign Direct Investment Induce Domestic Mergers? Open Economies Review, 22. 